\title{
Pengaruh Penambahan Serbuk Daun Stevia dan Pektin Daun Cincau Hijau Terhadap Sifat Fisik, Kimia, Dan Organoleptik Selai Buah Naga Merah
}

\author{
${\text { Verta Hedyana }{ }^{*} \text {, Noor Harini }}^{2}$, Moch. Wachid ${ }^{3}$ \\ ${ }^{1}$ Prodi Teknologi Pangan, Fakultas Pertanian Peternakan, Universitas Muhammadiyah Malang, \\ Malang, Indonesia \\ *Corresponding author email: vhedyana@gmail.com@gmail.com
}

\begin{abstract}
To increase the selling value and shelf life of dragon fruit, it can be processed into a jam. Jam made with the addition of pectin, sugar and citric acid. The pectin used in this study was pectin from green grass jelly leaf and use stevia powder as natural sweetener. This study used factorial randomized block design as a research design with different concentration of pectin $(0.75 \%, 1 \%, 1.25 \%)$ and different concentration of stevia leaf powder $(0.5 \%, 0.75 \%, 1 \%)$. The observed parameters include water content, $p H$, spread ability, color intensity, total dissolved solid, and organoleptic. The data obtained were analyzed using analysis of variance with a level of 5\% and continued with Duncan test. According to the result, pectin concentration of green grass jelly leaves and the concentration of stevia leaf powder affected the spread ability of the jam. There was an interaction between the pectin concentration of green grass jelly leaves and the concentration of stevia leaves on texture and color of dragon fruit jam. The results showed that the highest water content was $26.26 \%$, the highest $p H$ value was 4.38 , the highest total soluble solid value $10.53^{\circ} \mathrm{Brix}$, the highest spread ability value was $5.35 \mathrm{~cm}$, the highest $L$ value was 24.20, the highest texture organoleptic score 5.30, the highest color score was 5.50, the highest taste score was 4.9.
\end{abstract}

Keywords: green grass jelly, jam, pectin, red dragon fruit, stevia powder

\section{PENDAHULUAN}

Buah naga merah memiliki masa simpan \pm 7 hari pada suhu ruang (Istianingsih, 2013). Ketika musim panen, jumlah buah naga merah di Indonesia sangat melimpah sehingga sering kali dijual dengan harga yang murah. Salah satu cara untuk meningkatkan nilai jual sekaligus meningkatkan daya simpan buah naga, dapat dilakukan dengan cara mengolahnya menjadi suatu produk pangan yang memiliki daya simpan tinggi seperti selai.

Selai merupakan produk olahan buah yang memiliki tekstur semi padat. Selai dibuat dengan berbagai macam bahan, yaitu gula, pektin, dan asam sitrat. Menurut Kristanto (2003), daging buah naga memiliki kandungan pektin yang cukup rendah yaitu, sebesar 0,71\% dalam $100 \mathrm{~g}$ daging buah. Maka dari itu diperlukan pektin tambahan untuk menghasilkan selai yang baik.

Pektin merupakan salah satu bahan yang penting dalam pembuatan selai karena fungsinya sebagai agen pembentuk gel. Pektin dapat diekstrak dari 
bahan-bahan alami, salah satunya dari daun cincau hijau. Cincau hijau pohon memiliki pektin sebesar 15,2\% (Rachmawati, 2009) yang mana lebih tinggi dibandingkan dengan cincau hijau rambat yang memiliki pektin sebesar 1,36\% dan cincau hitam sebesar 11\% (Rahayu, 2013). Kandungan pektin yang cukup tinggi pada daun cincau hijau pohon dapat dimanfaatkan dalam pembuatan selai.

Selain pektin, bahan lain yang digunakan dalam pembuatan selai adalah gula. Penambahan gula bila terlalu banyak dikonsumsi dapat menimbulkan efek yang merugikan kesehatan, terutama untuk penderita diabetes. Oleh sebab itu pada penelitian ini digunakan konsentrasi gula yang lebih rendah yaitu $25 \%$ dan ditambahkan serbuk daun stevia sebagai pemanis alami yang aman dikonsumsi dan rendah kalori. Daun stevia merupakan sumber pemanis alami yang mempunyai tingkat kemanisan 200-300 kali lebih manis dari pada gula tebu. Menurut Buchori (2007) stevia termasuk spesies dari stevia rebaudiana. Rasa manis pada daun stevia berasal dari kandungan steviosida dan rebaudiosida. Menurut Das et al (2006), pada daun stevia kering mengandung steviosida sebanyak $13-20 \%$ dan rebaudiosida sebanyak 1-3\%, sehingga diharapkan penambahan pemanis alami stevia dalam pembuatan selai akan menghasilkan kemanisan yang optimal namun sangat rendah kalori sehingga dapat dikonsumsi oleh semua kalangan termasuk penderita diabetes maupun orang yang sedang diet rendah kalori.

\section{METODE PENELITIAN}

\section{Alat dan Bahan}

Alat yang digunakan pada penelitian ini adalah timbangan analitik (Pioner Ohaus PA413), pengering kabinet (Wanedi), colour reader (Minolta CS10), hand refraktometer (Atago tipe N-1 a (No. 2211)), oven (Romand tipe 5), $\mathrm{pH}$ meter (SI Analytics), cawan porselen, desikator, gelas ukur, beaker glass 50 ml, ayakan 100 mesh, thermometer, plat kaca, penggaris, kain saring, pipet tetes, spatula,dan aluminium foil.

Bahan yang digunakan pada penelitian ini adalah buah naga merah dengan umur panen 50 hari yang diperoleh dari rumah buah Dinoyo, daun stevia kering yang diperoleh dari Materia Medika Batu, daun cincau hijau pohon dengan panjang 10-15 cm berwarna hijau tua yang diperoleh dari Desa Ketan Ireng Kecamatan Prigen Pasuruan, asam sitrat, gula pasir, aquades, etanol 96\%.

\section{Rancangan Percobaan dan Analisis Data}

Penelitian ini menggunakan Rancangan Acak Kelompok (RAK) dengan dua faktor. Faktor pertama adalah konsentrasi pektin (P) yang terdiri dari 3 level $(0,75 \%, 1 \%, 1,25 \%)$ dan faktor kedua adalah konsentrasi serbuk daun stevia (S) yang terdiri dari 3 level $(0,5 \%, 0,75 \%, 1 \%)$. Masing-masing perlakuan diulang 
sebanyak 2 kali sehingga diperoleh 18 perlakuan. Data yang diperoleh dianalisis menggunakan ANOVA (Analysis of variance) apabila terdapat perlakuan berpengaruh terhadap parameter uji maka akan dilakukan uji banding DMRT (Duncan's Multiple Range Test) dengan taraf nyata 5\% ( $\mathrm{a}=0,05 \%)$.

\section{Ekstraksi Pektin Daun Cincau Hijau}

Proses ekstraksi pektin daun cincau hijau diawali dengan mencuci daun cincau hijau segar dengan air bersih, lalu dilakukan pengecilan ukuran daun cincau dengan ukuran $\pm 3 \mathrm{~cm} \times 1,5 \mathrm{~cm}$ agar proses pengeringan lebih cepat, kemudian daun cincau dikeringkan dengan cabinet dryer $50^{\circ} \mathrm{C}$ selama $24 \mathrm{jam}$. Daun yang sudah kering diblender sampai halus, sehingga diperoleh serbuk daun cincau hijau. Serbuk daun cincau hijau sebanyak 30 gram dimasukkan kedalambeaker glass $1000 \mathrm{ml}$ dan ditambah $600 \mathrm{ml}$ aquades, diaduk sampai rata menggunakan spatula sampai homogen. Kemudian dilakukan penyaringan menggunakan kain saring, sehingga diperoleh filtrat. Filtrat selanjutnya ditambah dengan etanol 96\% dengan perbandingan 1:1 sehingga diperoleh dua fraksi, yaitu fraksi gel dan cairan supernatan. Selanjutnya dilakukan penyaringan untuk memisahkan dua fraksi tersebut. Gel yang telah bebas dari air dan impurities lainnya dikeringkan dengan cabinet dryer pada suhu $50^{\circ} \mathrm{C}$ selama 5 jam sehingga diperoleh butiran-butiran kering ekstrak daun cincau hijau (pektin). Butiran-butiran pektin tersebut kemudian diblender sampai halus dan diayak dengan ayakan 100 mesh.

\section{Pembuatan Selai Buah Naga Merah}

Pembuatan selai buah naga diawali dengan melakukan pengupasan buah naga untuk memisahkan kulit dengan daging buahnya. Kemudian dilakukan penghalusan daging buah naga menggunakan blender sehingga diperoleh bubur buah naga. Langkah selanjutnya yaitu melakukan pemasakan bubur buah naga dengan suhu $70^{\circ} \mathrm{C}$ selama 30 menit dengan menambahkan semua bahan sesuai dengan formulasi yang telah ditentukan. Setelah selai berubah menjadi kental proses pemasakan dihentikan.

\section{Parameter Penelitian}

Parameter penelitian yang dilakukan yaitu analisa kadar air, $\mathrm{pH}$, total padatan terlarut, daya oles, intensitas warna, organoleptik tekstur, warna, dan rasa. Data yang diperoleh dianalisis menggunakan ANOVA (Analysis of variance). Apabila terdapat perlakuan berpengaruh terhadap parameter uji maka akan dilakukan uji banding DMRT (Duncan's Multiple Range Test) dengan taraf nyata $5 \%(\alpha=0,05 \%)$. 


\section{HASIL DAN PEMBAHASAN}

\section{Kadar Air}

Perlakuan penambahan pektin daun cincau hijau dan serbuk daun stevia tidak berpengaruh terhadap kadar air selai buah naga merah. Data kadar air pada masing-masing perlakuan dapat dilihat pada Gambar 1 dan Gambar 2. Berdasarkan Gambar 1 dapat diketahui bahwa kadar air selai buah naga cenderung menurun seiring dengan bertambahnya konsentrasi pektin daun cincau hijau yang diberikan. Hal ini dapat terjadi karena pektin memiliki sifat mengikat air dan dapat membentuk gel bersama gula dan asam. Pektin dapat mengalami penggumpalan dan membentuk serabut halus yang dapat memerangkap air sehingga jumlah air bebas berkurang dan kadar air pada selai buah naga merah menurun. Gula memiliki peran dalam proses dehidrasi yang menyebabkan ikatan hidrogen pada pektin lebih kuat dan membentuk jaringan polisakarida yang kompleks sehingga air terperangkap didalam jaringan (Shin et al. 2002).

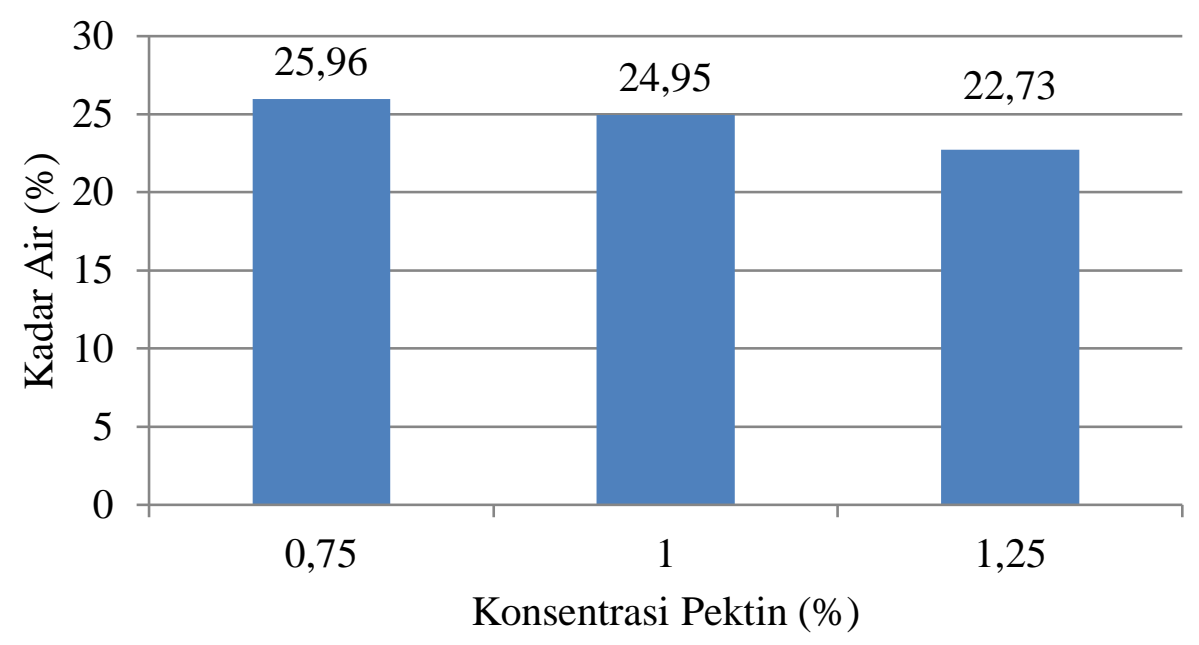

Gambar 1. Diagram Batang Kadar Air Selai Buah Naga Merah dengan Konsentrasi Pektin Daun Cincau Hijau yang Berbeda

Berdasarkan Gambar 2 dapat diketahui rerata kadar air yang dihasilkan menunjukkan tren yang cenderung menurun seiring dengan bertambahnya konsentrasi serbuk daun stevia. Daun stevia memiliki kandungan serat yang dapat menyerap air sehingga dapat mempengaruhi kadar air pada selai buah naga yang dihasilkan.Hal ini sesuai dengan Saribanon dkk (2018) yang menyatakan bahwa semakin banyak penambahan serbuk daun stevia, kadar air yang dihasilkan akan semakin rendah karena serbuk daun stevia mengandung serat yang dapat mengikat air dan menyebabkan kadar air pada selai menurun.

Laswati (2020) melakukan penelitian tentang pengaruh waktu pemanasan terhadap aktivitas antioksidan dan daya terima selai buah naga merah. Waktu 
pemanasan yang digunakan adalah 35, 40, 45, 50 dan 55 menit. Berdasarkan penelitian tersebut diketahui bahwa semakin lama waktu pemanasan maka akan menurunkan kadar air dan aktivitas antioksidan selai buah naga yang dihasilkan. Zadiyah (2019) melakukan pengujian daya simpan selai buah naga merah menggunakan metode Accelerated Shelf Life Testing (ASLT). Berdasarkan penelitian tersebut, selai buah naga merah memiliki daya simpan 99 hari di suhu $28^{\circ} \mathrm{C}$.

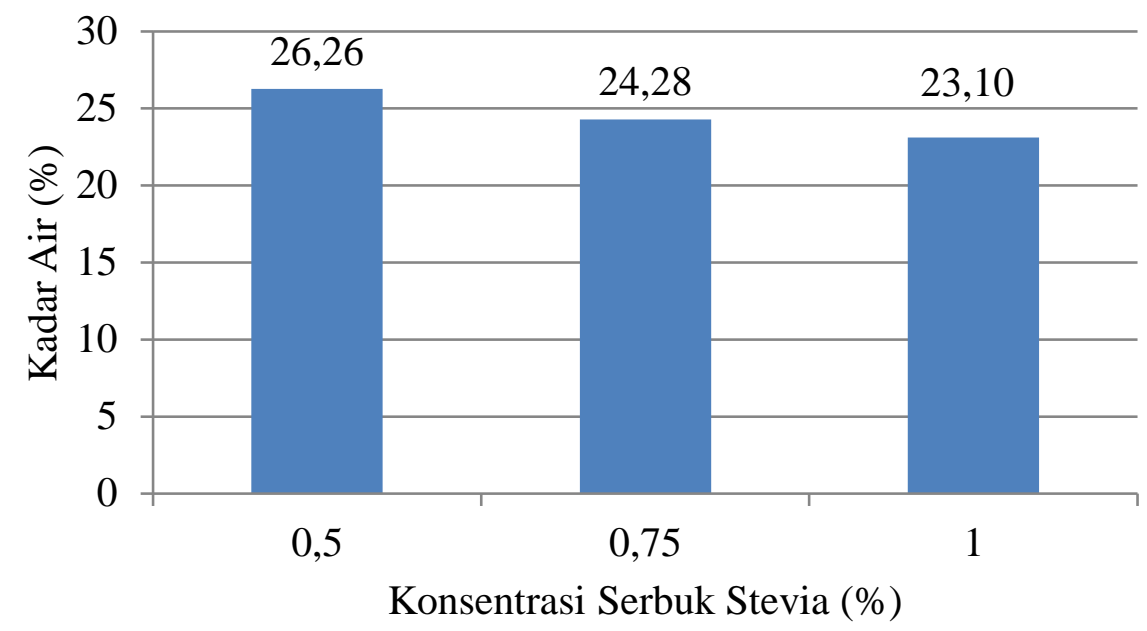

Gambar 2. Diagram Batang Kadar Air Selai Buah Naga Merah dengan Konsentrasi Serbuk Daun Stevia yang Berbeda

\section{Tingkat Keasaman (pH)}

Perlakuan penambahan pektin daun cincau hijau dan serbuk daun stevia tidak berpengaruh terhadap tingkat keasaman selai buah naga merah. Data tingkat keasaman pada masing-masing perlakuan dapat dilihat pada Gambar 3 dan Gambar 4. Berdasarkan Gambar 3, dapat diketahui bahwa tingkat keasaman selai buah naga memiliki selisih yang kecil antar perlakuan. Selai buah naga pada yang penambahan pektin $0,75 \%$ dan $1 \%$ memiliki $\mathrm{pH}$ yang sama yaitu sebesar 4,37, sedangkan selai buah naga dengan penambahan pektin 1,25\% memiliki nilai $\mathrm{pH}$ sebesar 4,36.

$\mathrm{pH}$ merupakan parameter yang menunjukkan tingkat keasaman pada suatu produk. Semakin tinggi nilai $\mathrm{pH}$, maka tingkat keasaman pada produk tersebut semakin rendah. Begitupula sebaliknya, semakin rendah nilai $\mathrm{pH}$ pada suatu produk, maka tingkat keasamannya semakin tinggi (Syahrumsyah et al. 2010). Penambahan pektin dapat mempengaruhi tingkat keasaman pada selai, karena pada pembuatan selai, pektin mengalami proses hidrolisis sehingga berubah menjadi asam pektat dan asam pektinat yang mengakibatkan tingkat keasaman selai semakin tinggi dengan bertambahnya konsentrasi pektin yang ditambahkan pada selai. 


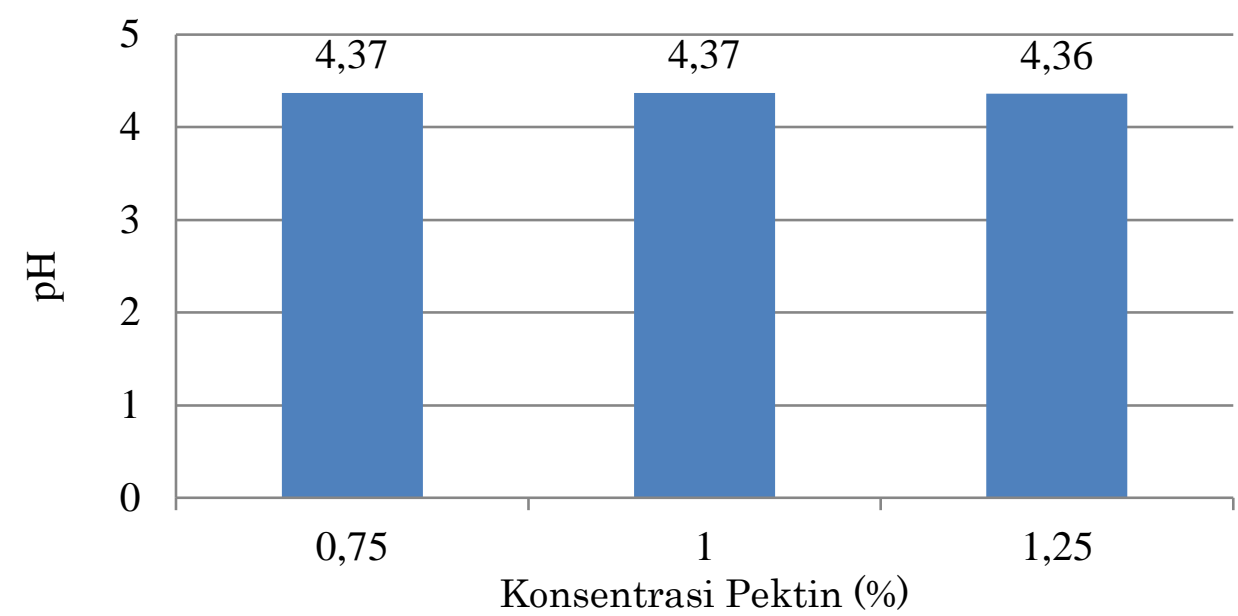

Gambar 3. Diagram Batang pH Selai Buah Naga Merah dengan Konsentrasi Pektin Daun Cincau Hijau yang Berbeda

Berdasarkan Gambar 4, dapat diketahui bahwa selai yang memiliki $\mathrm{pH}$ paling rendah adalah selai dengan penambahan serbuk daun stevia sebanyak $0,75 \%$ yaitu sebesar 4,35 , sedangkan selai yang memiliki $\mathrm{pH}$ paling tinggi adalah selai dengan perlakuan penambahan serbuk daun stevia sebanyak $1 \%$ yaitu sebesar 4,38. Penambahan serbuk daun stevia dapat mempengaruhi $\mathrm{pH}$ pada produk yang dihasilkan. Hal ini disebabkan karena serbuk daun stevia memiliki kandungan asam organik dan mineral yang merupakan senyawa-senyawa penyumbang $\mathrm{H}^{+}$. Salah satu mineral yang terkandung dalam daun stevia adalah mineral garam kalium yang bersifat asam sehingga dapat mempengaruhi penurunan $\mathrm{pH}$. Menurut Khausik et al. (2010), daun stevia memiliki kandungan kalium sebesar $893,0 \pm 8,55 \mathrm{mg} / 100 \mathrm{~g}$ daun kering.

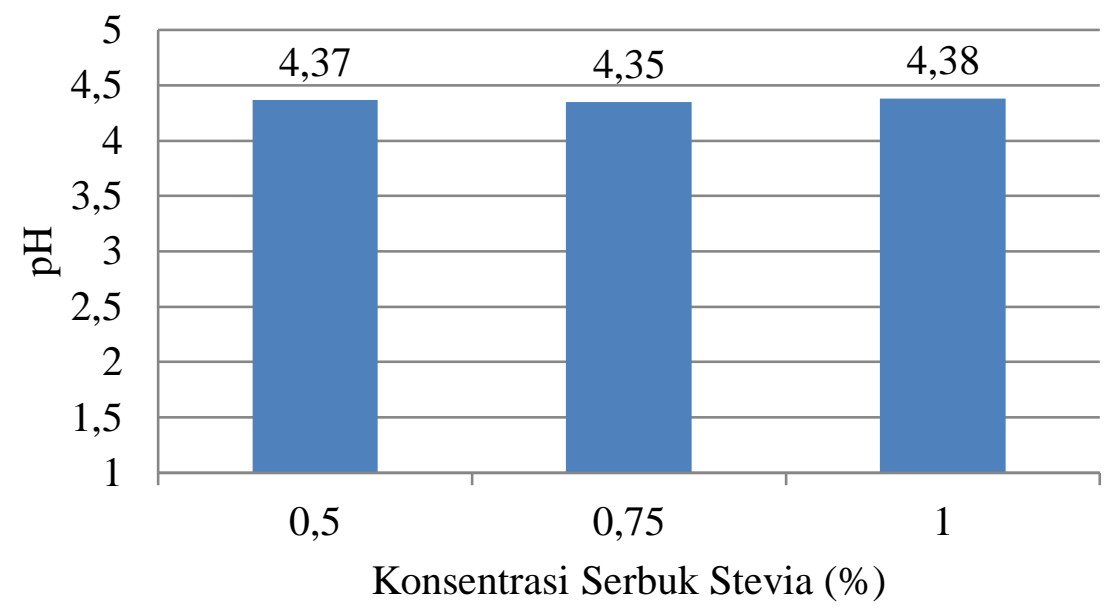

Gambar 4. Diagram Batang pH Selai Buah Naga Merah dengan Serbuk Daun Stevia yang Berbeda 


\section{Total Padatan Terlarut}

Perlakuan penambahan pektin daun cincau hijau dan serbuk daun stevia tidak berpengaruh terhadap total padatan terlarut selai buah naga merah. Data total padatan terlarut pada masing-masing perlakuan dapat dilihat pada Gambar 5 dan Gambar 6.

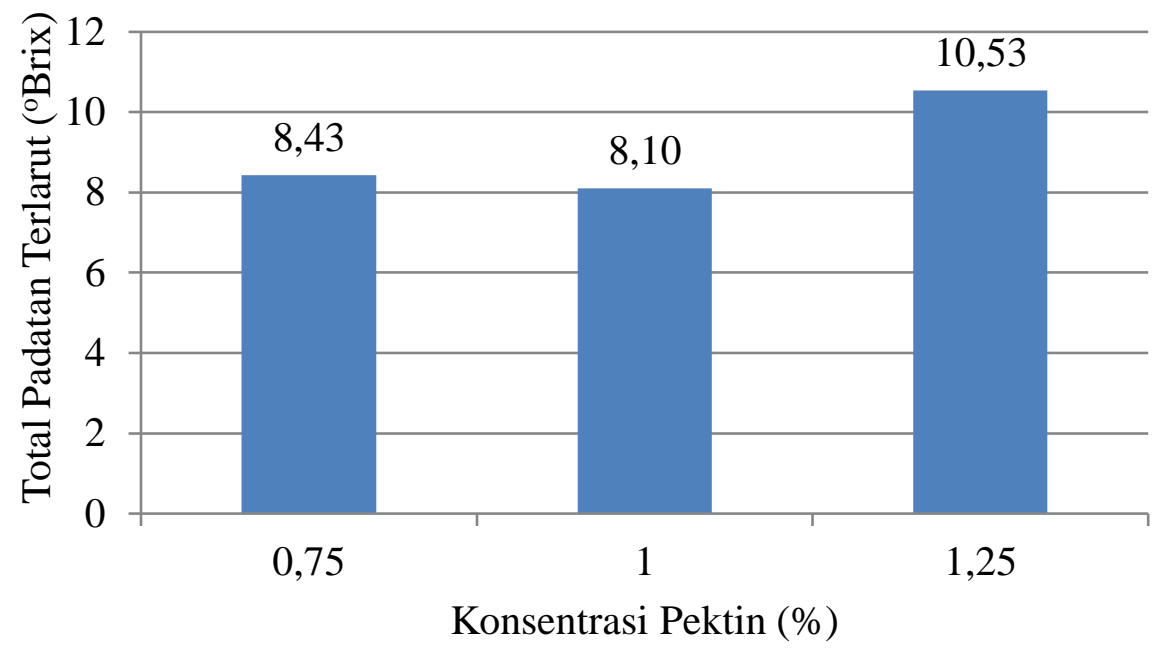

Gambar 5. Diagram Batang Total Padatan Terlarut Selai Buah Naga Merah dengan Konsentrasi Pektin Daun Cincau Hijau yang Berbeda

Berdasarkan diagram batang pada Gambar 5, dapat diketahui bahwa total padatan terlarut selai buah naga yang dihasilkan memiliki tren yang naik turun. Pada perlakuan penambahan pektin 1\% memiliki nilai total padatan terlarut yang paling rendah yaitu sebesar 8,10 oBrix. Sedangkan pada perlakuan penambahan pektin $1,25 \%$ memiliki nilai total padatan terlarut paling tinggi yaitu sebesar 10,53 ${ }^{\circ}$ Brix.

Penambahan pektin dapat mempengaruhi total padatan terlarut pada selai buah naga. Hal ini disebabkan karena pektin merupakan salah satu komponen penyusun total padatan terlarut. Sehingga semakin tinggi konsentrasi pektin yang ditambahkan, maka nilai total padatan terlarut akan semakin tinggi. Tetapi jika penambahan pektin terlalu banyak akan menyebabkan selai yang dihasilkan memiliki tekstur yang keras. Menurut Desrosier (2008), kandungan total padatan terlarut suatu bahan meliputi gula reduksi, gula non reduksi, asam organik, pektin dan protein.

Berdasarkan Gambar 6, dapat diketahui bahwa total padatan terlarut pada selai buah naga semakin meningkat seiring dengan bertambahnya konsentasi serbuk daun stevia yang ditambahkan. Pada penambahan serbuk daun stevia $0,5 \%$ memiliki nilai total padatan terlarut paling rendah yaitu 
sebesar $8,33^{\circ}$ Brix. Sedangkan nilai total padatan terlarut yang paling tinggi pada perlakuan penambahan serbuk daun stevia 1\% yaitu sebesar 9,97 ${ }^{\circ}$ Brix. Hal ini dapat terjadi karena serbuk daun stevia memiliki kandungan gula yang dapat menambah nilai total padatan terlarut pada produk selai buah naga. Total padatan terlarut yang dihasilkan belum memenuhi standart SNI yang menyatakan bahwa total padatan terlarut selai buah minimal 65\%. Total padatan terlarut yang dihasilkan masih belum memenuhi standart SNI disebabkan karena konsentrasi gula pasir yang ditambahkan lebih rendah dibandingkan dengan penambahan gula pasir dalam selai pada umumnya.

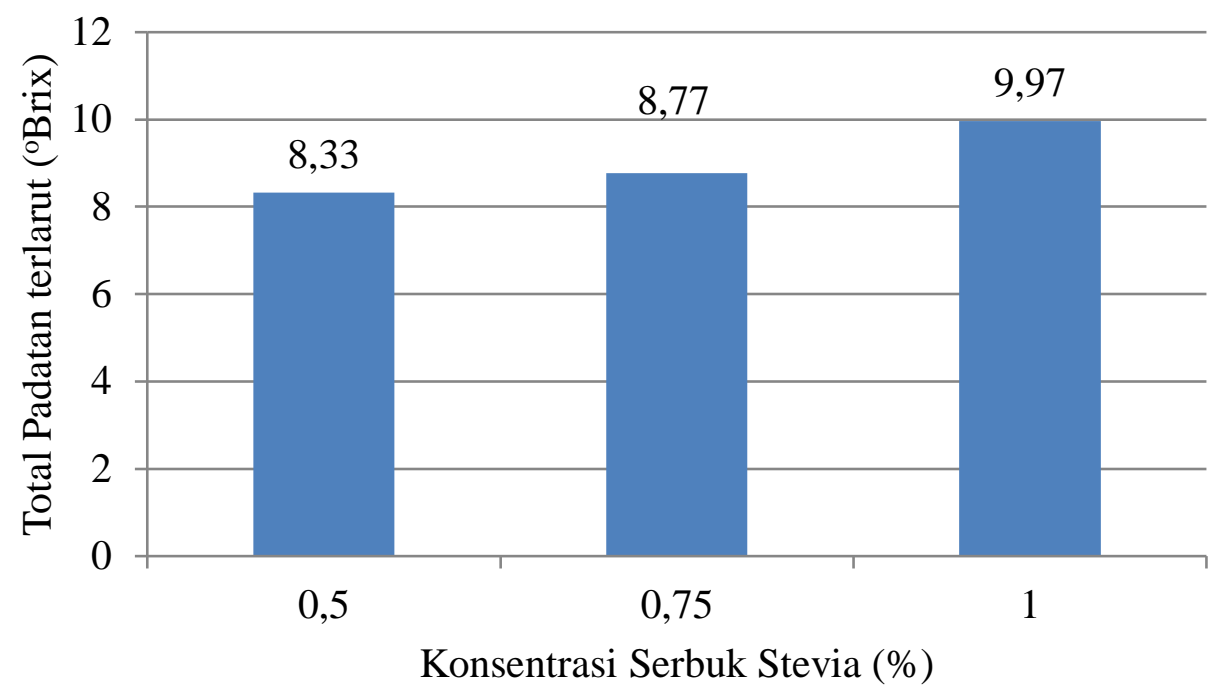

Gambar 6. Diagram Batang Total Padatan Terlarut Selai Buah Naga Merah dengan Konsentrasi Serbuk Daun Stevia yang Berbeda

\section{Daya Oles}

Berdasarkan analisa ragam, diketahui bahwa tidak terjadi interaksi antara pektin cincau hijau dan serbuk daun stevia terhadap daya oles selai buah naga merah. Konsentrasi pektin daun cincau hijau berpengaruh sangat nyata dan konsentrasi serbuk daun stevia berpengaruh nyata terhadap daya oles selai buah naga merah. Rerata daya oles selai buah naga merah tertera pada Tabel 1.

Berdasarkan Tabel 1, dapat diketahui bahwa daya oles selai buah naga semakin menurun seiring dengan bertambahnya konsentrasi pektin daun cincau hijau dan serbuk daun stevia, yang berarti selai yang dihasilkan semakin kental. Daya oles pada selai berkaitan dengan kadar airnya. Semakin tinggi kadar air pada selai, maka daya olesnya juga semakin tinggi karena tekstur selai akan lebih encer dan menyebabkan daya oles selai semakin panjang. Penambahan pektin daun cincau hijau dan serbuk daun stevia dapat mempengaruhi daya oles selai buah naga merah yang dihasilkan. Menurut Yuliani (2011), pektin bersifat dapat membentuk gel, semakin banyak pektin yang ditambahkan, maka gel 
yang terbentuk akan semakin keras sehingga selai yang dihasilkan semakin kental dan daya olesnya semakin rendah. Penambahan serbuk stevia dapat mempengaruhi daya oles selai karena kandunngan seratnya yang dapat menyerap air sehingga tekstur selai menjadi lebih kental dan daya olesnya rendah. Menurut Moguel et al.(2015), kadar serat pangan dalam daun stevia kering sebesar $32-38 \%$ dari seluruh komponen sifat kimia pada daun stevia.

Tabel 1.Rerata Daya Oles Selai Buah Naga Merah dengan Konsentrasi Pektin dan Daun Cincau Hijau dan Serbuk Daun Stevia yang Berbeda

\begin{tabular}{ll}
\hline Konsentrasi Pektin Daun Cincau Hijau $(\mathrm{P})$ & Daya Oles $(\mathrm{cm})$ \\
\hline P1 $(0,75 \%)$ & $5,35^{\mathrm{c}}$ \\
P2 $(1 \%)$ & $4,85^{\mathrm{b}}$ \\
P3 $(1,25 \%)$ & $4,13^{\mathrm{a}}$ \\
\hline Konsentrasi Serbuk Daun Stevia $(\mathrm{S})$ & Daya Oles $(\mathrm{cm})$ \\
\hline S1 $(0,5 \%)$ & $4,93^{\mathrm{c}}$ \\
S2 $(0,75 \%)$ & $4,78^{\mathrm{bc}}$ \\
S3 $(1 \%)$ & $4,61^{\mathrm{a}}$ \\
\hline
\end{tabular}

Keterangan: Angka-angka yang diikuti oleh huruf kecil yang berbeda menunjukkan berbeda nyata $(\mathrm{P}<0,05)$ dan angka-angka yang diikuti oleh huruf kecil yang sama menunjukkan berbeda tidak nyata.

\section{Intensitas Warna}

Perlakuan penambahan pektin daun cincau hijau dan serbuk daun stevia tidak berpengaruh terhadap intensitas warna selai buah naga merah. Data intensitas warna pada masing-masing perlakuan dapat dilihat pada Gambar 7 dan Gambar 8.

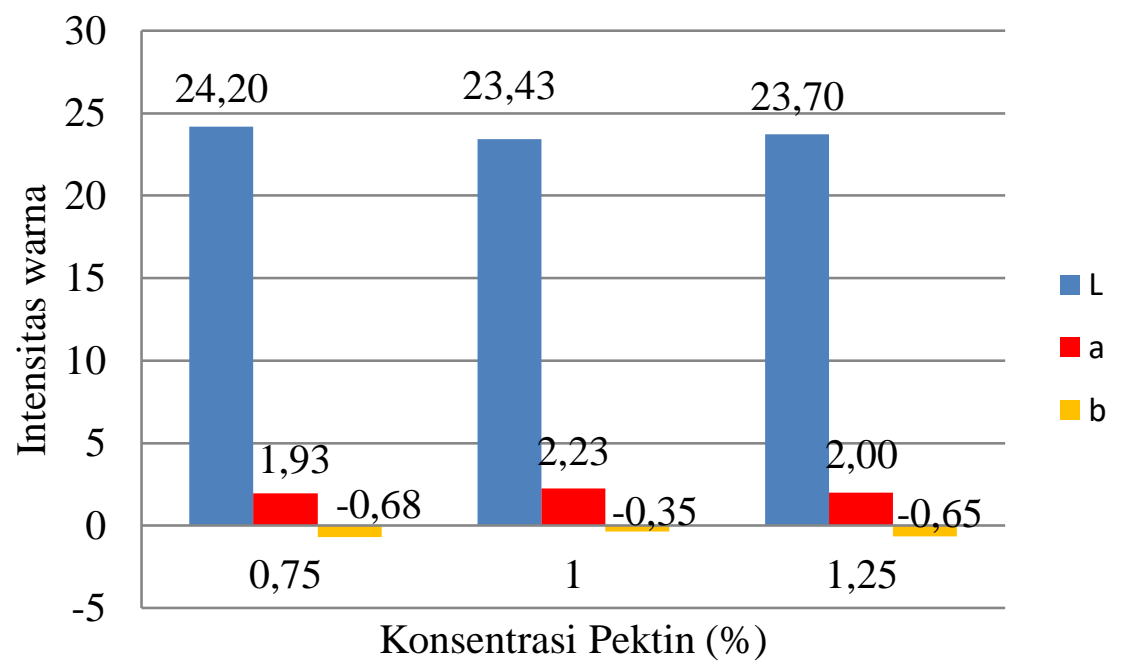

Gambar 7. Diagram Batang Intensitas Warna Selai Buah Naga Merah dengan Konsentrasi Pektin Daun Cincau Hijau yang Berbeda 
Berdasarkan diagram batang pada Gambar 7, dapat diketahui bahwa intensitas warna selai buah naga merah pada perlakuan perbedaan konsentrasi pektin memiliki selisih nilai intensitas warna yang tidak terlalu jauh antar perlakuan.Selai yang memiliki tingkat kecerahan (L) paling tinggi adalah selai dengan penambahan pektin $0,75 \%$ yaitu sebesar 24,20. Sedangkan selai yang memiliki tingkat kecerahan (L) paling rendah adalah selai dengan penambahan pektin $1 \%$ yaitu sebesar 23,43. Pada intensitas warna a (tingkat kemerahan), perlakuan yang memiliki nilai tertinggi adalah perlakuan penambahan pektin 1\% yaitu sebesar 2,23, dan perlakuan yang memiliki nilai a (tingkat kemerahan) paling rendah adalah pada perlakuan penambahan pektin $0,75 \%$ yaitu sebesar 1,93. Pada nilai warna b (tingkat kebiruan), perlakuan yang memiliki nilai paling rendah adalah perlakuan penambahan pektin $0,75 \%$ yaitu sebesar $-0,68$, sedangkan perlakuan yang memiliki nilai b (tingkat kebiruan) paling tinggi adalah perlakuan penambahan pektin $1 \%$ yaitu sebesar -0,35. Warna selai yang diperoleh cenderung gelap karena pektin daun cincau hijau yang ditambahkan berwarna hijau sehingga mempengaruhi warna selai yang dihasilkan.

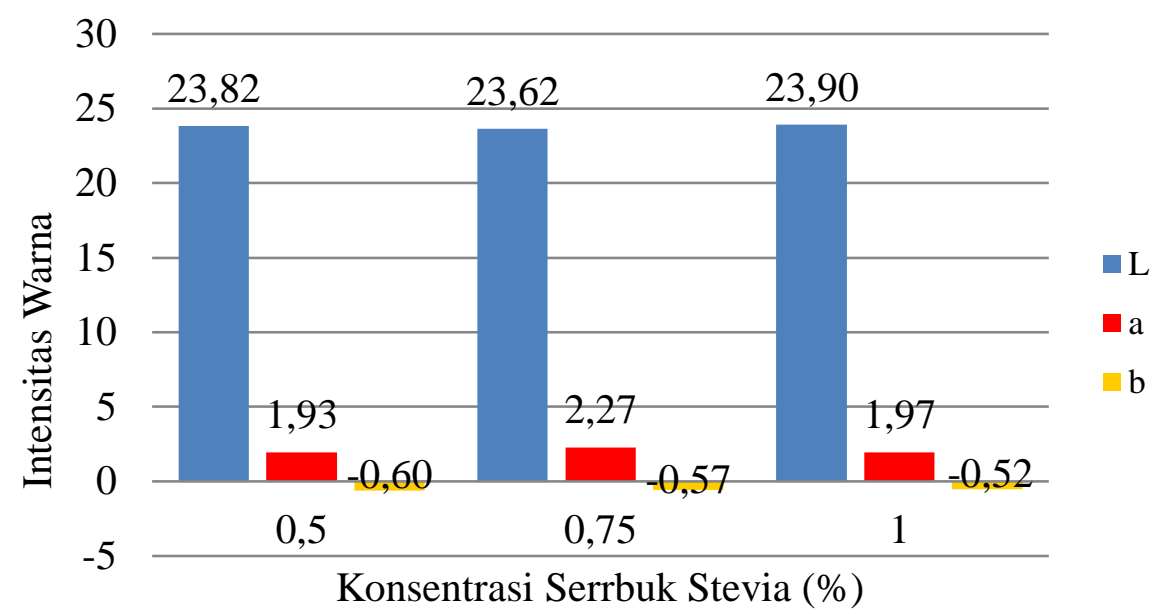

Gambar 8. Diagram Batang Intensitas Warna Selai Buah Naga Merah dengan Konsentrasi Serbuk Daun Stevia yang Berbeda.

Berdasarkan diagram batang pada Gambar 8, dapat diketahui bahwa intensitas warna selai buah naga merah pada perlakuan perbedaan konsentrasi serbuk stevia juga memiliki selisih nilai intensitas warna yang tidak terlalu jauh antar perlakuan. Selai yang memiliki tingkat kecerahan (L) paling tinggi adalah selai dengan penambahan serbuk stevia 1\% yaitu sebesar 23,90. Sedangkan selai yang memiliki tingkat kecerahan (L) paling rendah adalah selai dengan penambahan serbuk stevia $0,75 \%$ yaitu sebesar 23,62 . Pada intensitas warna a (tingkat kemerahan), perlakuan yang memiliki nilai tertinggi adalah perlakuan penambahan serbuk stevia $0,75 \%$ yaitu sebesar 2,27, dan perlakuan yang 
memiliki nilai a (tingkat kemerahan) paling rendah adalah pada perlakuan penambahan serbuk stevia $0,5 \%$ yaitu sebesar 1,93 . Pada nilai warna b (tingkat kebiruan), perlakuan yang memiliki nilai paling rendah adalah perlakuan penambahan serbuk stevia $0,5 \%$ yaitu sebesar $-0,60$, sedangkan perlakuan yang memiliki nilai b (tingkat kebiruan) paling tinggi adalah perlakuan penambahan serbuk stevia $1 \%$ yaitu sebesar $-0,52$.

Menurut Javanmard dan Endan (2010), faktor-faktor yang dapat berpengaruh pada perubahan warna antara lain temperatur, oksigen, dan $\mathrm{pH}$. Degradasi sukrosa dapat menyebabkan polimerisasi ketika proses pemanasan sehingga mengakibatkan perubahan warna pada selai. Warna selai yang diperoleh cenderung gelap karena serbuk daun stevia yang ditambahkan berwarna hijau sehingga mempengaruhi warna selai yang dihasilkan.

\section{Organoleptik}

\section{Tekstur}

Perlakuan penambahan pektin daun cincau hijau dan serbuk daun stevia berpengaruh nyata terhadap organoleptik tekstur selai buah naga merah. Data total padatan terlarut pada masing-masing perlakuan dapat dilihat pada Tabel 2 .

Tabel 2. Rerata Skor Organoleptik Tekstur Selai Buah Naga Merah dengan Interaksi Pektin Daun Cincau Hijau dan Serbuk Daun Stevia

\begin{tabular}{ll}
\hline \multicolumn{1}{c}{ Perlakuan } & Tekstur \\
\hline P1S1 (Pektin cincau 0,75\% + serbuk stevia 0,5\%) & $3,80^{\mathrm{a}}$ \\
P1S2 (Pektin cincau 0,75\% + serbuk stevia 0,75\%) & $3,80^{\mathrm{a}}$ \\
P1S3 (Pektin cincau 0,75\% + serbuk stevia 1\%) & $3,95^{\mathrm{ab}}$ \\
P2S1 (Pektin cincau 1\% + serbuk stevia 0,5\%) & $4,20^{\mathrm{bc}}$ \\
P2S2 (Pektin cincau 1\% + serbuk stevia 0,75\%) & $4,45^{\mathrm{cd}}$ \\
P2S3 (Pektin cincau 1\% + serbuk stevia 1\%) & $4,70^{\mathrm{d}}$ \\
P3S1 (Pektin cincau 1,25\% + serbuk stevia 0,5\%) & $5,05^{\mathrm{e}}$ \\
P3S2 (Pektin cincau 1,25\% + serbuk stevia 0,75\%) & $5,10^{\mathrm{e}}$ \\
P3S3 (Pektin cincau 1,25\% + serbuk stevia 1\%) & $5,30^{\mathrm{e}}$ \\
\hline
\end{tabular}

Keterangan: Angka-angka yang diikuti huruf yang sama menunjukkan perbedaan yang tidak nyata $(5 \%)$

Keterangan:

1. Sangat cair

2. Cair

3. Agak cair

4. Agak kental

5. Kental

6. Sangat kental

7. Amat sangat kental 
Berdasarkan hasil yang diperoleh dapat diketahui bahwa semakin tinggi konsentrasi pektin daun cincau hijau dan serbuk stevia yang ditambahkan, tekstur selai yang dihasilkan semakin kental. Hal ini terjadi karena tekstur pada selai dipengaruhi oleh adanya air, pektin, gula, dan asam. Menurut Rianto, dkk (2017), banyaknya keberadaan pektin dalam bahan, maka gel yang dihasilkan akan semakin keras. Penambahan serbuk daun stevia juga mempengaruhi tekstur selai buah naga, karena serbuk daun stevia memiliki kandungan serat yang dapat mengikat air sehingga tekstur selai yang dihasilkan semakin kental. Tekstur selai yang dihasilkan mendapatkan penilaian yang cenderung cair menurut panelis. Hal ini disebabkan karena konsentrasi gula yang ditambahkan lebih rendah dibandingkan dengan selai pada umumnya.

\section{Warna}

Perlakuan penambahan pektin daun cincau hijau dan serbuk daun stevia berpengaruh nyata terhadap organoleptik warna selai buah naga merah. Data total padatan terlarut pada masing-masing perlakuan dapat dilihat pada Tabel 3.

Tabel 3. Skor Organoleptik Warna Selai Buah Naga Merah dengan Interaksi Pektin Daun Cincau Hijau dan Serbuk Daun Stevia

\begin{tabular}{ll}
\hline Perlakuan & Warna \\
\hline P1S1 (Pektin cincau 0,75\% + serbuk stevia 0,5\%) & $4,55^{\mathrm{ab}}$ \\
P1S2 (Pektin cincau 0,75\% + serbuk stevia 0,75\%) & $5,05^{\mathrm{c}}$ \\
P1S3 (Pektin cincau 0,75\% + serbuk stevia 1\%) & $5,05^{\mathrm{c}}$ \\
P2S1 (Pektin cincau 1\% + serbuk stevia 0,5\%) & $5,20^{\mathrm{cd}}$ \\
P2S2 (Pektin cincau 1\% + serbuk stevia 0,75\%) & $4,85^{\mathrm{bc}}$ \\
P2S3 (Pektin cincau 1\% + serbuk stevia 1\%) & $4,30^{\mathrm{a}}$ \\
P3S1 (Pektin cincau 1,25\% + serbuk stevia 0,5\%) & $5,05^{\mathrm{c}}$ \\
P3S2 (Pektin cincau 1,25\% + serbuk stevia 0,75\%) & $5,50^{\mathrm{d}}$ \\
P3S3 (Pektin cincau 1,25\% + serbuk stevia 1\%) & $5,00^{\mathrm{c}}$ \\
\hline
\end{tabular}

Keterangan: Angka-angka yang diikuti huruf yang sama menunjukkan perbedaan yang tidak nyata

Keterangan:

1. Sangat tidak menarik

2. Tidak menarik

3. Agak tidak menarik

4. Agak menarik

5. Menarik

6. Sangat menarik

7. Amat sangat menarik

Pada Tabel 3 menunjukkan rerata penilaian panelis terhadap tekstur selai buah naga merah. Menurut panelis, selai yang memiliki warna paling 
menarik adalah selai dengan perlakuan P3S2 (Pektin cincau 1,25\% + serbuk stevia $0,75 \%$ ) dengan nilai 5,50 yang tidak berbeda nyata dengan perlakuan P2S1 (Pektin cincau $1 \%+$ serbuk stevia $0,5 \%$ ). Sedangkan selai yang memiliki nilai paling rendah menurut panelis adalah selai dengan perlakuan P2S3 (Pektin cincau $1 \%+$ serbuk stevia 1\%) dengan nilai 4,30 (agak menarik) yang tidak berbeda nyata dengan perlakuan P1S1 (Pektin cincau 0,75\% + serbuk stevia $0,5 \%)$.

Penilaian warna selai buah naga merah yang dihasilkan pada setiap perlakuan memiliki rentang yang tidak terlalu jauh yaitu agak menarik sampai menarik. Menurut Setyaningsih et al. (2010), warna termasuk daya tarik yang utama sebelum panelis menilai sifat yang lain. Warna selai buah naga merah yang dihasilkan adalah merah keunguan. Warna yang dihasilkan ini berasal dari buah naga yang berwarna merah keunguan. Tetapi warna selai yang dihasilkan lebih gelap dibandingkan dengan warna buah naga. Hal ini terjadi karena akibat dari penambahan serbuk daun stevia dan pektin daun cincau hijau yang berwarna hijau, sehingga warna selai yang dihasilkan lebih gelap.

\section{Rasa}

Perlakuan penambahan pektin daun cincau hijau dan serbuk daun stevia tidak berpengaruh terhadap organoleptik rasa selai buah naga merah. Data total padatan terlarut pada masing-masing perlakuan dapat dilihat pada Gambar 9.

Pada Gambar 9 menunjukkan rerata penilaian panelis terhadap rasa selai buah naga merah. Menurut panelis, selai yang memiliki rasa paling manis diantara perlakuan lainnya adalah selai dengan perlakuan P2S2 (Pektin cincau $1 \%+$ serbuk stevia $0,75 \%$ ) dengan nilai 4,90 . Sedangkan selai yang memiliki nilai paling rendah menurut panelis adalah selai dengan perlakuan P1S2 (Pektin cincau $0,75 \%+$ serbuk stevia $0,75 \%$ ) dengan nilai 4,15 (agak manis). Rerata penliaian tingkat kemanisan selai buah naga merah yang dihasilkan tidak memiliki selisih yang terlalu jauh antar perlakuan.

Rasa manis pada selai dapat disebabkan oleh adanya serbuk daun stevia yang ditambahkan. Menurut Prissilia (2014), daun stevia memiliki kandungan glikosida yang dapat menghasilkan rasa manis. Glikosida yang terkandung dalam daun stevia terdiri dari 2 konstituen utama yaitu steviosida dan rebaudiosida, dimana steviosida memiliki tingkat kemanisan 300 kali dari sukrosa dan rebaudiosida memiliki tingkat kemanisan sebesar 400 kali lebih besar dari sukrosa. 


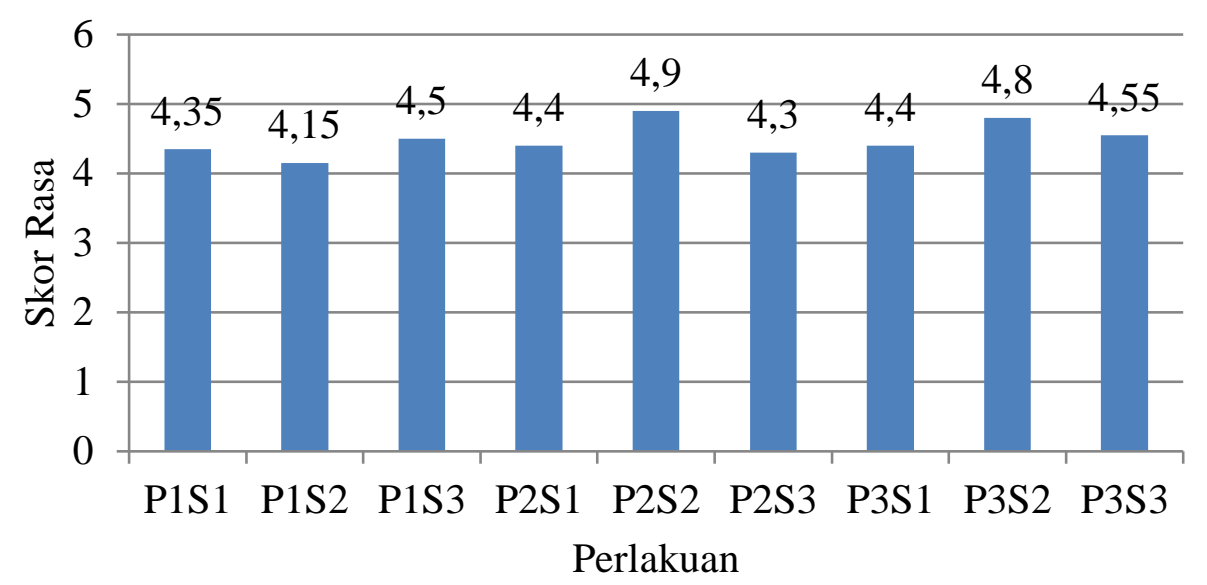

Keterangan:

1. Sangat tidak manis

2. Tidak manis

3. Agak tidak manis

4. Agak manis

5. Manis

6. Sangat manis

7. Amat sangat manis

Gambar 9. Diagram Batang Skor Rasa Selai Buah Naga Merah dengan Konsentrasi Serbuk Daun Stevia yang Berbeda

\begin{abstract}
Keterangan:
P1S1: pektin $0,75 \%+$ serbuk stevia $0,5 \%(\mathrm{~b} / \mathrm{b})$

P1S2: pektin $0,75 \%+$ serbuk stevia $0,75 \%(\mathrm{~b} / \mathrm{b})$

P1S3: pektin $0,75 \%+$ serbuk stevia $1 \%(\mathrm{~b} / \mathrm{b})$

P2S1: pektin $1 \%+$ serbuk stevia $0,5 \%(\mathrm{~b} / \mathrm{b})$

P2S2: pektin $1 \%+$ serbuk stevia $0,75 \%(b / b)$

P2S3: pektin $1 \%+$ serbuk stevia $1 \%(\mathrm{~b} / \mathrm{b})$

P3S1: pektin $1,25 \%+$ serbuk stevia $0,5 \%(\mathrm{~b} / \mathrm{b})$

P3S2: pektin $1,25 \%+$ serbuk stevia $0,75 \%(\mathrm{~b} / \mathrm{b})$

P3S3: pektin 1,25\% + serbuk stevia $1 \%(\mathrm{~b} / \mathrm{b})$
\end{abstract}

\title{
KESIMPULAN
}

Berdasarkan hasil penelitian yang telah dilakukan dapat diambil kesimpulan bahwa terjadi interaksi antara konsentrasi pektin daun cincau hijau dan serbuk daun stevia terhadap organoleptik tekstur dan warna selai buah naga merah. Konsentrasi pektin daun cincau hijau berpengaruh sangat nyata terhadap daya oles selai buah naga merah dan tidak berpengaruh terhadap kadar air, $\mathrm{pH}$, total padatan terlarut, intensitas warna, dan organoleptik rasa selai buah naga merah. Konsentrasi serbuk daun stevia berpengaruh nyata terhadap daya oles selai buah naga merah dan tidak berpengaruh terhadap kadar air, $\mathrm{pH}$, total padatan terlarut, intensitas warna organoleptik rasa selai buah naga merah.

\section{REFERENSI}

Buchori, L. 2007. Pembuatan Gula Non Karsinogenik Non Kalori Dari Daun Stevia. Jurnal UNDIP. Reaktor, Vol. 11 No.2. Hal: 57-60. DOI: $10.14710 /$ reaktor.11.2.57-60 
Das. K., D. Raman., P. E. Rajaesekharan. 2006. Estabilishment and Maintanance of Callus of Stevia Rebaudiana Bertoni Under Aseptic Environment. Natural Product Radient. Vol 5(5), pp 373-376

Desrosier, Norman W. 2008. The Technology of Food preservation, Third Edition (Teknologi Pengawetan Pangan, Edisi Ketiga). Penerjemah: Muchji Mulijohardjo.Penerbit Universitas Indonesia. Jakarta.

Istianingsih, T. 2013. Pengaruh Umur Panen dan Suhu Simpan terhadap Umur Simpan Buah Naga Super Red (Hylocereus costaricensis). Jurnal Hortikultura. 4(1) 54-61

Javanmard, M dan J. Endan. 2010. A Survey on Rheogical Properties of Fruit Jams. Journal of Chemical Engineering and Aplication 1(1):1-7.

Kaushik, R., N. Pradeep, V. Vamshi, M. Geetha, and A. Usha. 2010. Nutrient Composition of Cultivated Stevia Leaves and TheInfluence of Polyphenols and Plant Pigments on Sensory and Antioxidant Properties of Leaf Extracts. Journal of Food Science. 47:7-33. DOI:10.1007/s13197-0100011-7

Kristanto. 2008. Buah Naga Pembudidayaan di Pot dan di Kebun. Penebar Swadaya. Jakarta

Laswati. D.T. 2020. Pengaruh Waktu Pemanasan terhadap Aktivitas Antioksidan dan Daya Terima Selai Buah Naga Merah (Hylocereus polyrhizus). Jurnal Teknologi Pangan. Universitas Widya Mataram. Yogyakarta. DOI: 10.37631/agrotech.v3i1.170

Moguel, O., B. Yolanda., L. Diana., A. Carbera., R. Maira., S. Campos., C. J. Ruiz. 2015. Studies on Drying Characteristic, Nutritional Composition, and Antioxidant Properties of Stevia Rebaudiana Bertoni Leaves. International Agrophysics. 29 (3): 323-31. DOI: 10.1515/intag-2015-0039

Prissilia, P. 2014. Kualitas Selai Mangga Kweni Rendah Kalori dengan Variasi Rebaudiosida A. Jurnal Teknobiologi. Fakultas Teknobiologi. Universitas Atmajaya. Yogyakarta

Rachmawati, A.K., Anandito, R.B.K., dan Manuhara, G.J. 2010. Ekstraksi dan Karakterisasi Pektin pada Cincau Hijau (Premna oblongifolia) untuk Pembuatan Edible Film. Jurnal Biofarmasi. 8(1):1-10. DOI: 10.13057/biofar/f080101

Saribanon, T., I. Fitriana., dan A. Sampurno. 2018. Substitusi Gula Pasir dengan Tepung Daun Stevia (Stevia rebaudiana Bert) terhadap Sifat Fisikokimia dan Organoleptik Selai Albedo Semangka. Jurusan Teknologi Hasil Pertanian. Fakultas Pertanian, Universitas Semarang

Setyaningsih., Dwi., A. Apriyantono., dan M. P. Sari. 2010. Analisis Sensori untuk Industri Pangan dan Agro.IPB Press. Bogor. 
Shin, J.E., L. Salim dan P. Cornillom. 2002. The Effect of Centrifugation on Agar/Sucrose Gels. Journal of Food Hydrocolloids 16(2):89-94. DOI: 10.1016/S0268-005X(01)00058-3

Syahrumsyah, H., W. Murdianto., Pramanti. 2010. Pengaruh Penambahan Karboksi Metil Selulosa (CMC) dan Tingkat Kematangan Buah Nanas terhadap Mutu Selai Buah Nanas. Jurnal Teknologi Pertanian 6(1): 3440 .

Yuliani, H.R. 2011. Karakterisasi Selai Tempurung Kelapa Muda. Prosiding Seminar Nasional Teknik Kimia.Politeknik Ujung Pandang.

Zadiyah., S.H. Anwar., S.Q. Ayun., I.S. Nasution. 2019. Shelf Life Estimation of Red Dragon Fruit Jam using Accelerated Shelf Life Testing (ASLT) Method. IOP Conf. Series: Earth and Environment Science 365, 012029. doi:10.1088/1755-1315/365/1/012029 